\title{
Impact of Practices by Human Resource on Job Satisfaction of Foreign \& Local Bank Employee
}

\author{
Ahmed Muneeb Mehta \\ Lecturer, Hailey College of Banking and Finance, University of the Punjab, Lahore, \\ Pakistan
}

Tel: 0092-333-4519789

Muhammad Bilal Ahmad

PhD Scholar, Hailey College of Commerce, University of the Punjab, Lahore, Pakistan

Muhammad Ahsan Khan

MPhil, Hailey College of Commerce, University of the Punjab, Lahore

E-mail: ahsankhanverdeg@gmail.com

Tel: 0092-322-622920

Rabia Shahid

MPhil, Hailey College of Commerce, University of the Punjab, Lahore

E-mail: Rabiashahid092@gmail.com

Received: October 30, 2018 Accepted: December 2, 2018 Published: December 12, 2018

doi: 10.5296/jsss.v6i1.14041ＵRL: https://doi.org/10.5296/jsss.v6i1.14041

\begin{abstract}
The job satisfaction is more important in any firm. This research has a bearing of HR practices e.g. performance analysis, promotional practices, compensation practices, operating atmosphere and superior association on job satisfaction of workers in banking sector of Pakistan. Research study reveals that however workers operating in numerous native and foreign banks in Lahore have totally different levels of satisfaction. This analysis conducted on the premise of primary information collected from the branches of Bank Alfalah, Habib
\end{abstract}


Bank Ltd. and NIB bank in Lahore. SPSS sixteen is employed to research the information by mistreatment $\mathrm{T}$ take a look at, correlation and multivariate analysis. OLS-regression methodology is employed to test the normality and one-dimensionality of knowledge and alternative assumptions helps to test the link between variables. By applying simple regression model, we have a tendency to determine that there's a powerful $\&$ positive relationship between the various human resource practices and job satisfaction of workers.

Keywords: Job satisfaction, Human resource practices, Ordinary least square, Model, Banking

\section{Introduction}

"Job satisfaction" of workers are the basic factor of performance of workers within the organizations. If workers operating in any association are happy by HRM, the workers turnover are goes down that will increase successively the productivity of the organization. Larger the employee's satisfaction in any enterprises greater is the potency of the workers lead towards the profits \& the efficiency. Banking sector shows in Islamic Republic of Pakistan may be an exceptional growth over the amount. Because of competitiveness in open market the banks need to persist and contend within the developing banking system in Pakistan. To satisfy \& retain of workers in banking sector from their jobs is that the basic downside in sector of banks. The aim of this study is to work out either or not the HR sector fulfills their workers with their actions and the way HR Practices will mark the work satisfaction of workers in native monetary banking sectors like "NIB, Habib Bank Ltd and foreign banks like Bank Alfalah Ltd". higher human resource management (HRM) plays a central role in enrichment of productivity of a corporation (Bloom, 2007). HRM practices might also have an effect on the worker turnout and productivity might increase (Sels, 2006). Consistent with Delaware (2004) job autonomy, low wages, low security and dearth of expectation for promotion negatively have an effect on job satisfaction of workers. Worker retentive is additionally possible to be a crucial for organization performance. If the corporate isn't being able to retain their workers, it will not be capable to capitalize on human assets developed at intervals the organization (Shekshnia, 1994). Level of satisfaction of the workers operating as a team is extremely vital as a result of it directly result their job performance (James, 1996).

\subsection{Objectives}

There are some purposes which are as follows:

To explore that however analysis skills, robust structure of payment \& operating setting enthusiastic about the satisfaction of the work.

To explore that however job holding satisfy the workers.

however promotional activities will have an effect on the work satisfaction.

To seek out out the options making lesser flip over in a company.

To seek out that that human resource practices have an effect on foreign or native banks.

\subsection{Hypothesis}

The link between HR practices and job satisfaction of workers provides to the subsequent hypothesis: 
-H0: there's no important relationship between human resource practices and job satisfaction of workers.

-H1: there's no important relationship between performance analysis and job satisfaction of workers.

-H2: there's no important relationship between promotion practices and job satisfaction of workers.

-H3: there's no important relationship between compensation practices and job satisfaction of workers.

-H4: there's no important relationship between human operating surroundings and job satisfaction of workers.

-H5: there's no important relationship between superior relationship practices and job satisfaction of workers.

\section{Literature Review}

Previous studies on the work satisfaction demonstrates that job satisfaction is a crucial think about any business particularly in banking sector as a result of trade banking system industry could be a competitive further as developing industry currently a days. Range of studies has explored that management turnover could be a test for the businesses \& completely different enterprises have various strategies to diminish their turnover (APA, 2001).

The non-public banks particularly created a cut throat competition by giving the new merchandise and services so as to realize a lot of market share. The utilization patterns in banking sector modified the main focus toward targets and performance instead of previous expertise and loyalty. Thus remuneration and job satisfaction becomes the first issue for the banking staff that required attentions thus on reach the future objectives of the bank (Islam \& Saha, 2003).

Khalid and Irshad (2010) describes that staff of personal banks were a lot of glad with remuneration, recognition and dealing hours as compared to public sector bank staffwhereas \{the staff|the workers|the staff\} of public sector are a lot of glad with their job security as compared to personal sector bank employees.

According to Nathaniel Hawthorne (1930) "A happy employee could be a productive worker". Employee's engagement brazenly impacts the monetary findings of a company. deciding, co-ordination, performance of the worker, Appraisals, Rewards, Carrier development are a lot of vital to worker commitment whereas coaching and performance appraisals aren't considerably link to worker engagement (Saima \& Rehman, 2009).

In line with Hunjra and Rehman (2010) that a significant relationship is gift between human resource management and job satisfaction like job autonomy, work atmosphere \& leadership behavior. Together with the findings of male $\&$ feminine each staff has completely various level of satisfaction.

Muhammad Azar ruler, Qamar and Fariha (2010) explains the result of human resource practices (carrier growth openings, superior funding, operating atmosphere, Prizes) on worker retaining. So, there is a significant relationship between human resource management practices associated worker retaining that shifts towards the rise in potency of an organization. 
Tooksoon and Mudor (2011) explain that HRM Practices like superior association, training \& campaign will increase job satisfaction that ends the less retention. Quantity is employee's satisfaction of their job. So, there are 5 parts of job satisfaction, work, salary and acknowledgement were tested further overall job satisfaction.

\subsection{Job Satisfaction}

"Job satisfaction is contentment (or lack of it) arising out of interplay of employee's positive and negative feelings toward his or her work". (www. business dictionary.com). Independent variable is human resource practices.

\subsection{Human Resource Practices}

The body self-control of growing and hiring workers in order that they develop a lot of appreciated to the organization. (www.businessdictionary.com). The HR practices that effects the task satisfaction are as follows;

-Performance Practices analysis

- Promotional practices

- Compensational Plans

- Work Environmental Conditions

-And association of higher-up is measured because the freelance variables.

-Management Human resource means that "to choose, develop, encourage and maintain human resource within the organization". It selects the primary right human resources or employees (i.e. Managers and employees). It trains and develops, encourage them recognition and rewards. It provides them the simplest operating conditions.

\subsection{Performance Appraisal}

Performance appraisal may be significant element of HRM. From victimization this instrument we are able to better task satisfaction \& efficiency of staff within the enterprises (Brown \& Benson, 2003). Benefits by totally various banks choose pay inducement and performance judgement HR department shifts toward job satisfaction that leads toward low flip over. But connection has tested with banking sector in Asian nation.

\subsection{Promotion Practices}

Teseema \& Soeters (2006) found significant association between worker performance and promotion practice, but unit of time practices together with 'vacancies stuffed from within' on advantage are found absolutely correlate with work satisfaction .Synergetic systems of unit of time observes (including advantage decision of promotion) cause greater performance of a company. To higher than previous studies it's presumed that HR practices had important association on satisfaction of workers.

\subsection{Compensation Practices}

Human capital is a motivation, enterprises pay an important element to attaining greater performance staff by paying them high pay incentives and accommodation plans to them. Great compensation strategies will cause larger satisfaction of staff and attract staff towards firms. While, it is presumed that there is significant association between compensation plans and staff satisfactions.

\subsection{Work Environment}


There's a positive and vital connection between the task satisfaction and also the HRM practices like team work environment. Work atmosphere improves efficiency, growth and skills of employees by developing firms supported the principle of affection, honesty and attention to realize target of devotion and satisfaction of employees with enterprises (Aydin \& Ceylan, 2009). The companies involves within the banking business are "moon-faced" with increasing opposition thanks to entrance of recent companies. So, as to vie within the growing market. The organizations must target the supply depends on banking service quality at low cost costs. So, competitive atmosphere, the retaining of trained and adept personnel may be a big problem of the banking sector within the country. Thus, operating atmosphere could have vital result on the task satisfaction of the workers.

\subsection{Supervisory Relationship}

Leadership encourages within the improvement of efficiency, development and skills of employees by developing perspective of firm supported the principle of affection, honesty and care to realize the objectives of loyalty and satisfaction of employees with enterprises (Aydin \& Ceylan, 2009).

Asian nation is experiencing the outstanding growth. Banking system in Asian nation experiencing with an excellent encounters with respect to fight during this up-growing market higher-up association with the employee's show a crucial part for the full team to figure with efficiency. Retaining well trained and high performance personnel is big issue of unit of time department.

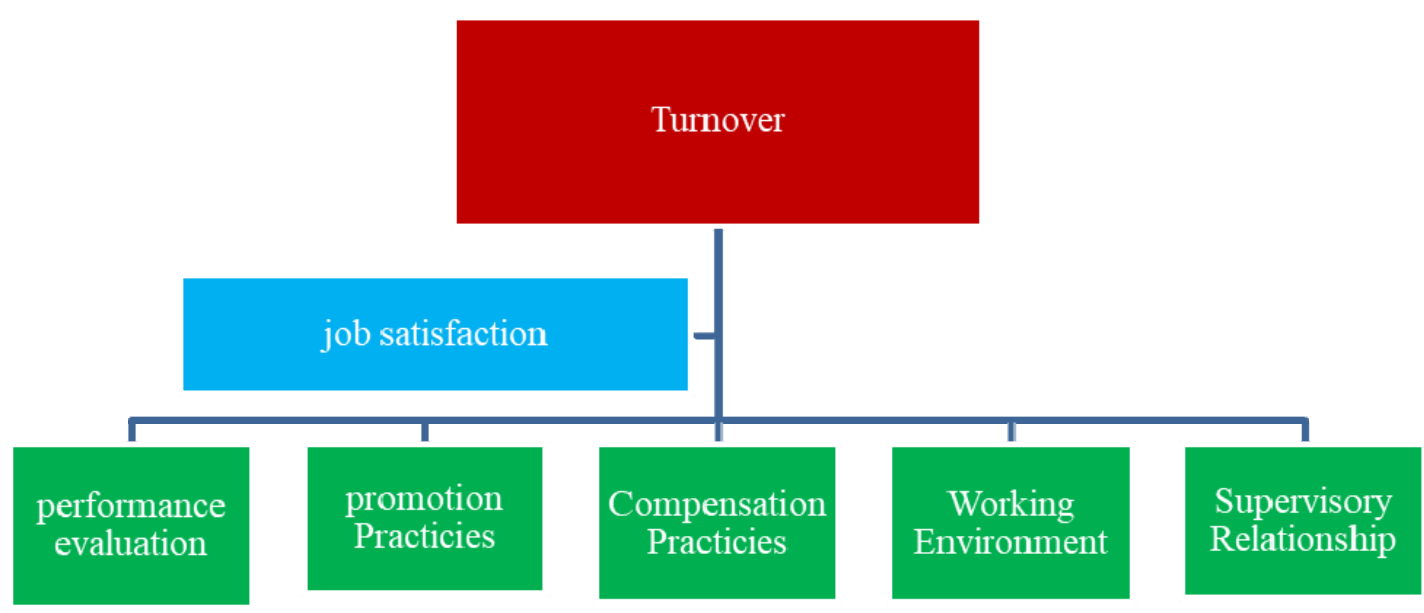

Theoretical framework

\section{Research Design}

The direct variable is Job Satisfaction of workers and therefore the indirect variable is human resource practices. All direct and indirect variables are measured on the premise of opinion gathered from form collected from workers of foreign and native banking sectors. Target population is workers of bank Alfalah, Habib bank and NIB bank of metropolis. Primary knowledge is employed during this analysis. A form is distributed in numerous branches of 3 
banks of those foreign \& native banks. 300 forms are floated out of those three hundred questionnaire two hundred were came and twenty five was uncompleted. Samples of a hundred and fifty questionnaires were chosen arbitrarily for this analysis. Sample of fifty is chosen from every bank on the premise of glad sampling.

\section{Data Analysis}

The 1st research is to tests the normality and one-dimensionality of cross sectional knowledge utilized in analysis. For this purpose normal least sq. (OLS) technique is employed and model based mostly is on the simple regression. Simple regression is employed to specify the character of the relation between the 2 variables. OLS approach is most popular to over different tests as a result of results of simple regression in OLS indicate one-dimensionality and normality of information in increased manner. OLS technique conjointly provides info regarding homoscedasticity or hetroscadicity and co-linearity of information or multi co-linearity.

The basic assumptions for OLS regression model are as:

- Model is direct within the parameters.

- The first moment of the errors is usually Zero

- Residuals have the consistent variance.

-Experimental variable should be related with the variable.

Variables whose are independent and whole model must be numerous.

Lightweight of dialogue in past studies and to explore the link between the HR practices and therefore the job satisfaction of workers, equation are as follows:

$$
\mathrm{Y}=\beta 0+\beta 1 \mathrm{X} 1+\beta 2 \mathrm{X} 2+\beta 3 \mathrm{X} 3+\beta 4 \mathrm{X} 4+\beta 5 \mathrm{X} 5
$$

Where $\beta 0=$ Intercept

$\beta 1=$ impact of experimental variable

$\mathrm{Y}=$ variable Job Satisfaction

$\mathrm{X} 1=$ experimental variable Performance Appraisal

$\mathrm{X} 2=$ experimental variable Promotion Practices

$\mathrm{X} 3$ = experimental variable Compensation Practices

$\mathrm{X} 4=$ experimental variable operating atmosphere

X5 = experimental variable higher-up Relationship

\section{Findings}

The effects of the variables have been analyzed by OLS-regression model. The findings of data by utilizing linear regression in OLS are shown under the tables.

Table 1. Descriptive statistics

\begin{tabular}{lll}
\hline & Mean & Std. Deviation \\
\hline Job satisfaction & 3.7433 & .75693 \\
Performance evaluation & 3.4667 & .77214 \\
\hline
\end{tabular}


Promotion practices

3.2200

.87944

Compensation practices

3.0033

.95801

Working environment

3.7400

.65977

Supervisory relationship

3.9533

.74037

Table 2. ANOVA ${ }^{\mathrm{b}}$

\begin{tabular}{|c|c|c|c|c|c|}
\hline Model & Sum of Squares & $\mathrm{df}$ & Mean Square & $\mathrm{F}$ & Sig. \\
\hline 1 Regression & 28.690 & 5 & 5.738 & 14.578 & $.000^{\mathrm{a}}$ \\
\hline Residual & 56.679 & 144 & .394 & & \\
\hline Total & 85.368 & 149 & & & \\
\hline
\end{tabular}

a. "Predictors: (Constant), supervisory practices, performance evaluation, working environment, compensation practices, promotion practices"

b. Dependent Variable: job satisfaction

Table 3. Correlations

\begin{tabular}{|c|c|c|c|c|c|c|c|}
\hline & & $\begin{array}{l}\text { Job } \\
\text { satisfaction }\end{array}$ & $\begin{array}{l}\text { Performance } \\
\text { evaluation }\end{array}$ & $\begin{array}{l}\text { Promotion } \\
\text { practices }\end{array}$ & $\begin{array}{l}\text { Compensation } \\
\text { practices }\end{array}$ & $\begin{array}{l}\text { Working } \\
\text { environment }\end{array}$ & $\begin{array}{l}\text { Supervisory } \\
\text { practices }\end{array}$ \\
\hline \multirow[t]{6}{*}{$\begin{array}{l}\text { Pearson } \\
\text { Correlation }\end{array}$} & $\begin{array}{l}\text { Job } \\
\text { satisfaction }\end{array}$ & 1.000 & .244 & .365 & .411 & .410 & .455 \\
\hline & $\begin{array}{l}\text { performance } \\
\text { evaluation }\end{array}$ & .244 & 1.000 & .646 & .458 & .240 & .229 \\
\hline & $\begin{array}{l}\text { Promotion } \\
\text { practices }\end{array}$ & .365 & .646 & 1.000 & .559 & .244 & .382 \\
\hline & $\begin{array}{l}\text { Compensation } \\
\text { practices }\end{array}$ & .411 & .458 & .559 & 1.000 & .293 & .308 \\
\hline & $\begin{array}{l}\text { Working } \\
\text { environment }\end{array}$ & .410 & .240 & .244 & .293 & 1.000 & .373 \\
\hline & $\begin{array}{l}\text { Supervisory } \\
\text { practices }\end{array}$ & .455 & .229 & .382 & .308 & .373 & 1.000 \\
\hline \multirow[t]{2}{*}{$\begin{array}{l}\text { Sig. } \\
\text { (1-tailed) }\end{array}$} & $\begin{array}{l}\text { Job } \\
\text { satisfaction }\end{array}$ & . & .001 & .000 & .000 & .000 & .000 \\
\hline & $\begin{array}{l}\text { Performance } \\
\text { evaluation }\end{array}$ & .001 & . & .000 & .000 & .002 & .002 \\
\hline
\end{tabular}


Promotion

practices

.000

.000

.000

.001

.000

Compensation

practices

.000

.000

.000

.000

.000

Working

environment

.000

.002

.001

.000

.000

Supervisory

practices

.000

.002

.000

.000

.000

\section{Histogram}

\section{Dependent Variable: jobsatisfaction}

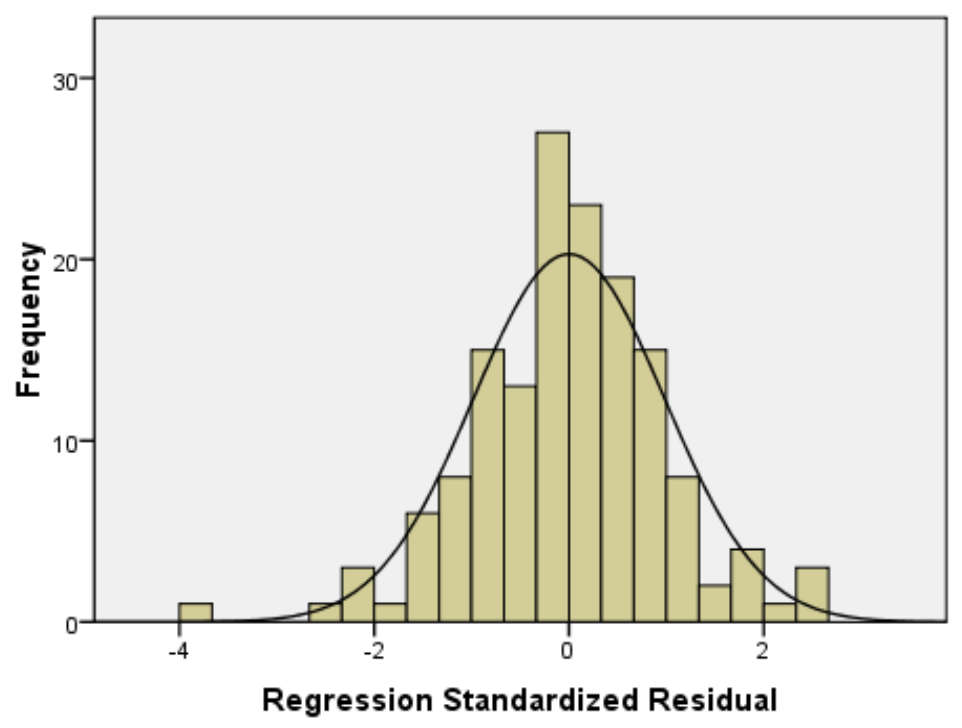

Mean $=2.00 \mathrm{E}-16$ Std. Dev $=0.983$ 


\section{Normal P-P Plot of Regression Standardized Residual}

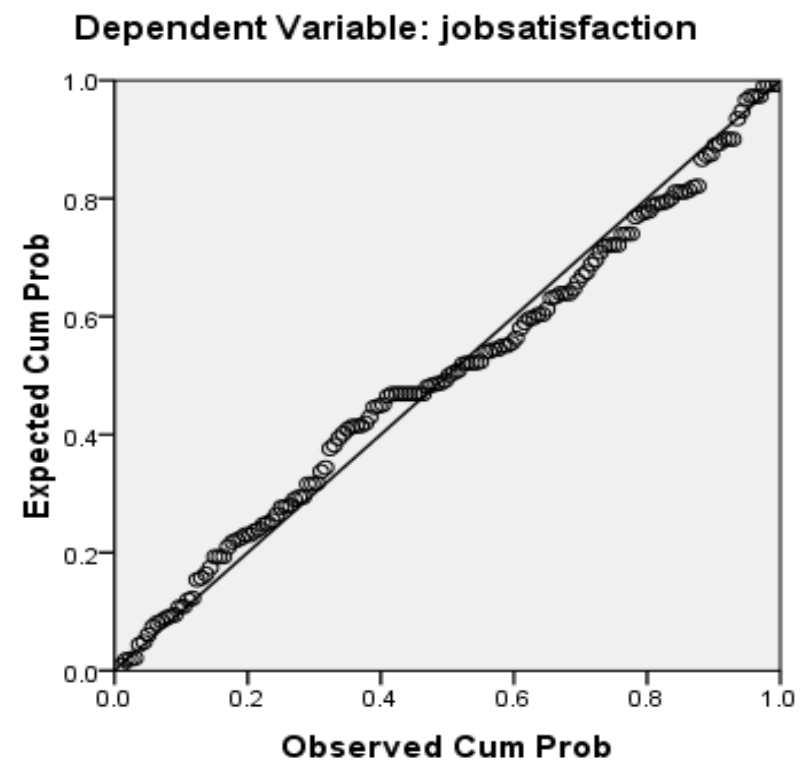

\section{Results Summary}

Findings explain the subsequent results:

R2 shows correlation is constant. Worth of R2 is zero.336 that explains the relationship between dependent and freelance variables isn't Brobdingnag Ian. Experimental variable HR practices are examined by the "performance analysis, promotion practices". Compensation practices, work setting \& therefore the superior practices within the ideal justify thirty three amendments in job satisfaction that's examined by worker ideas.

F-statistic i.e., zero indicates that whole model is important and justify the fitness of good of the model.

T-statistic i.e., zero indicates that compensation practices, operating setting and superior association are vital showing values but .05 and therefore the performance appraisal and therefore the promotional practices aren't vital showing values of larger than .05 individual variables in model.

Model is important therefore the regression of $\mathrm{y}$ on $\mathrm{x}$ becomes;

Job satisfaction relation

Values of variance inflation issue and therefore the tolerance indicate that multi co one-dimensionality doesn't exist between 2 variables.

Worth of Durbin Watson shows that one. 722 there's very little drawback of homoscedasticity exists in knowledge.

take a look at of Chi sq. shows that its worth is zero. This shows chi sq. is that the vital.

Graphs indicate that knowledge approaches to one-dimensionality that's constatation of OLS-regression model. The bar graph shows normality of knowledge. 


\section{Conclusion}

Researchers examined that the connection between trade easement and economic condition in Asian country. There are some points as follows;

Results explain that HR practices have impact on the duty satisfaction.

Null hypothesis is not supported just in case of compensation, operating setting and superior relationship and $\mathrm{H} 3, \mathrm{H} 4$ and $\mathrm{H} 5$ is accepted within the case of Performance, Promotion and $\mathrm{H} 1$ and $\mathrm{H} 2$ are rejected.

Human resource practices like compensation, working environment and supervisory relationship showing 0 values of t-test level of significance shows that these variable have significant impact on the job satisfaction of employees in the foreign and local banks of Pakistan but performance and promotion showing greater value than .05 level of significance shows that these two variables are not significant to the job satisfaction.

The empirical results show that human resource practices including compensation practices, work environment and supervisory relationship has great impact on the job satisfaction of bank employees which directly affects the performance of employee's leads toward lesser turnover. Individual results from questionnaire shows that employees in foreign bank BAL are more satisfied regarding their salary structure and the performance evaluation but employees in local banks like HBL and NIB are more satisfied regarding their job security or safety.

\section{References}

Bloom, N., \& Van Reenen, J. (2007). Measuring and explaining management practices across firms and countries. The Quarterly Journal of Economics, 122(4), 1351-1408. https://doi.org/10.1162/qjec.2007.122.4.1351

Hossain, M. (2014). Job satisfaction of bank employees in Bangladesh.

Hunjra, A. I., Chani, D., Aslam, S., Azam, M., \& Rehman, K. (2010). Factors effecting job satisfaction of employees in Pakistani banking sector.

Khalid, S., \& Irshad, M. Z. (2010). Job satisfaction among bank employees in Punjab, Pakistan: A comparative study. European journal of social sciences, 17(4), 570-577.

Mehta, A. M., \& Khawaja, F. N. (2014). A Review and Research Agenda; Impact of Human Resource Practices on Job Satisfaction of Employees in Foreign and Local Banks of Pakistan. Journal of Human Resources Management and Labor Studies, 2(2), 149-158.

Muhammad Azar Sheikh, W.- U. Q. (n.d.). Impact of Human Resource Management (HRM) Practicies on Employees Retention. case study .

Rehman, M. S. (2011). Human Resource Practices and Job Performance in Pakistan, Analysis of a Hypothesized Model. Information Management and Business Review, 3(2), 78-90.

Rehman, S. S. (2009). Impact of HR Practicies \& Organizations Development on Employee Engagement in Banking Sector of Pakistan, 50-62.

Sardar, S., Rehman, A., Yousaf, U., \& Aijaz, A. (2011). Impact of HR practices on employee 
engagement in banking sector of Pakistan. Interdisciplinary Journal of Contemporary Research in Business, 2(9), 378-389.

Sels, L., De Winne, S., Maes, J., Delmotte, J., Faems, D., \& Forrier, A. (2006). Unravelling the HRM-Performance link: Value-creating and cost-increasing effects of small business HRM. Journal of Management Studies, 43(2), 319-342. https://doi.org/10.1111/j.1467-64 86.2006.00592.x

Tooksoon, H. M. P. (2011). Conceptual framework on the relationship between human resource management practices, job satisfaction, and turnover. Journal of Economics and Behavioral Studies, 2(2), 41-49.

\section{Copyright Disclaimer}

Copyright for this article is retained by the author(s), with first publication rights granted to the journal.

This is an open-access article distributed under the terms and conditions of the Creative Commons Attribution license (http://creativecommons.org/licenses/by/3.0/). 